\title{
The Levellers, political literacy and contemporary Citizenship education in England
}

\begin{abstract}
This paper analyses the concept of political literacy (as introduced in the 1998 Crick Report) in relation to Citizenship in the English National Curriculum. It argues that political literacy has not been sufficiently emphasised or facilitated within this foundation subject and that the concept is particularly important for students at a time of considerable political and social conflict in England (and elsewhere). The authors state that engagement with the ideas and practices of the Levellers (a political group writing and agitating at the time of the Civil Wars) could enable students and teachers to explore political literacy (especially the implications of social media) by looking at a political group who utilised mass pamphlettering as a form of political communication. The paper will also investigate the context of Citizenship within the English National Curriculum and some of the philosophical concerns around Citizenship education. It contains a section placing the Levellers in their contemporary and historiographical contexts.
\end{abstract}

Keywords: citizenship, curriculum, political literacy, Levellers, England.

\section{Introduction}

The issue of Citizenship as a National Curriculum subject in England has acquired a new force and interest with recent political events such as the "Trojan Horse' affair in Birmingham, the EU referendum and recent acts of terrorism in London and Manchester. The government has introduced (in 2014 and 2015) new guidance for schools on colleges on 'Fundamental British Values' and the PREVENT duty (to counteract radicalisation and terrorism). These are expected to be included in any discussion of the Citizenship curriculum. But where does political literacy (as understood and defined by the 1998 Crick Report) factor into this discussion? Crick saw political literacy as integral to any study of Citizenship and recent events offer new opportunities for students and teachers to discuss what it means to participate as citizens in articulating ideas and formulating potential change.

We believe study of the Levellers (a mid-seventeenth century group of political thinkers and agitators) as part of a Citizenship curriculum could help to bring out the possibilities and implications of political literacy for teachers and students in the contemporary classroom and beyond. The Levellers were living in a comparably volatile political environment where questions of loyalty, belonging, identity and empowerment were being discussed. The Levellers were also active 
at a time when print literature was becoming a mass form of political communication in a sense that is not dissimilar to the widespread use of social media as part of contemporary political discussion and argument.

Pamphlettering was a (relatively) quick and cheap way of communicating political views directly to specific audiences whilst avoiding 'official' channels and agencies - these processes are not altogther dissimilar to the use of tweets, blogs and notifications in today's digital culture.The Levellers' use of the written word as a form of active citizenship could be an inspiration (and a warning) to current students.

It is important that this paper also frames discussion on what 'citizenship' means in the current political and philosophical climate. This will be addressed in the sections immediately below on the evolution of Citizenship education in England, the concept of 'political literacy' and how this relates to debate on citizenship from liberal, communitarian and radical perspectives in academia (focussing particularly on the work of Chantal Mouffe).

\section{Political literacy in the context of Crick and the current National Curriculum}

In terms of contemporary education in England, the issue of political literacy gained widespread discussion and debate after the publication of Education for citizenship and the teaching of democracy in schools (1998). This report, widely referred to as the 'Crick Report' after the name of the Chairman of the report's committee, Professor Bernard Crick, provided the impetus for citizenship to become a subject in the English National Curriculum at key stages 3 and 4 in 2002. The report defines political literacy as

Pupils learning about ... how to make themselves effective in public life through knowledge, skills and values - what can be called 'political literacy', seeking for a term that is wider than political knowledge alone. The term 'public life' is used in its broadest sense to encompass realistic knowledge of and preparation for conflict resolution and decision-making related to the main econmoic and social problems of the day (QCA, 1998: 13).

The current programme of study for citizenship in the National Curriculum states that

citizenship education should foster pupils' keen awareness and understanding of democracy, government and how laws are made and upheld. Teaching should equip pupils with the skills and knowledge to explore political and social issues critically, to weigh evidence, debate and make reasoned arguments (DfE, 2013).

It is not particularly clear what is meant by the skills and knowledge associated within citizenship beyond the broad and very general notions of 'the law and 
justice system in our society' and 'the skills to think critically and debate political questions'. In this sense, the Crick Report is much more comprehensive on the skills, aptitudes, knowledge and understanding required of pupils at key stages 3 and 4 in order to demonstrate and extend their awareness of political literacy (QCA, 1998: 49-52). It could be claimed that citizenship education in the National Curriculum presents a considerably 'watered down' version of what the Crick committee envisaged for education in political literacy in England.

But how does the concept of political literacy (in terms of citizenship education) relate to the more general debates regarding citizenship in the philosophy of education? It is to this question that we now must turn.

\section{Political literacy and philosophy of education}

\section{Liberalism, conceptions of the good and 'neutrality'}

Citizenship has been a live issue in philosophy of education (and it has been for political philosophy as well) for several decades. This has been due to several factors. Firstly, as introduced above, citizenship and, by extension, political literacy, has become part of the English National Curriculum and this has triggered considerable discussion on the role of citizenship within a given curriculum and how this relates to the aims of state education in late twentieth/early twenty-first century societies. This discussion has formed part of a much wider debate within political philosophy on what constitutes citizenship in an era of where the attachment of citizenship to the modern nation state was becoming increasingly problematised (due to the multicultural nature of many states, increased globalisation and the rise of regional identities).

Charles Taylor, neatly and somewhat lightheartedly, summarised the liberal/communitarian debate on citizenship in political philosophy as consisting of 'two "teams", with people like Rawls, Dworkin, Nagel, and Scanlon on one side (team L), and Sandel, MacIntryre, and Walzer on the other (team C)' (Taylor in Matravers and Pike, 2003: 195). The debate was, inevitably, more nuanced and complex than a simple categorisation into 'schools' or 'teams' would permit and centred largely around the question: 'Can a state be neutral or objective regarding the varied (and often conflicting) belief systems citizens may hold?' Alongside this question is often posed the follow-up: 'Can a liberal (and purportedly 'neutral') state ever generate enough identification from those citizens within its territory to make the necessary sacrifices for it to survive and thrive?' Thinkers who are sympathetic to liberal political philosophy tend to argue that states should avoid advocating a particular conception of the good life whilst philosophers more sympathetic to what has been termed 'communitarianism' have tended to regard particular conceptions of the good life as an integral (and perhaps inevitable) element of what it means to be a citizen in a given state or society. 
Where people stand regarding contemporary citizenship will inevitably influence their views on how it should be taught (or if it should be taught) in schools and colleges. It will also affect how the concept of political literacy is interpreted and addressed. Marianna Papastephanou, for instance, has argued that 'the search for teaching political attitudes and values has so far limited education to the role of passive recipient of some fashionable theories' (Papastephanou, 2005: 501). In her view, a liberal stance on the notion of citizenship 'cannot avoid comprehensiveness' (Papastephanou, 2005: 501). If, as Papastephanou argues, nation states that view themselves as liberal cannot avoid the practice of prioritising or advocating certain belief systems or worldviews over others (that might be equally as valid), what does this mean for political literacy? The knowledge, skills and values associated with political literacy will reflect those belief systems and worldviews - what is appropriate as political discourse and the ways and means in which such discourse is articulated will be determined by what the society concerned deems as acceptable. For critics like Papastephanou, political literacy cannot be neutral between different conceptions of the good. This has potential implications for tolerance and diversity in the classroom and amongst the student body in general. If liberalism is itself a worldview, then how accommodating is it to critics of that worldview? Are some political values (and the knowledge inherent within them) inevitably locked out of any exploration of political literacy? As Enslin, Pendlebury and Tjiattas succinctly put it, this is 'the problem of how people learn to be democrats in the circumstances of diversity and plurality that prevail in most democracies' (Enslin et al., 2001: 115).

\section{Citizenship-as-practice}

The way that political literacy is currently framed within citizenship education has been problematic for certain philosophers of education. Biesta and Lawy have concerns that 'recent developments in citizenship education have stayed quite close to the individualistic conception of citizenship that emerged in Britain in the 1980s' (Biesta and Lawy, 2006: 70). The authors go on to say:

The ... problem with the idea of citizenship education is that it is largely aimed at individual young people ... [this] individualizes the problem of young people's citizenship - and in doing so follows the neo-liberal line of thinking in which individuals are blamed for their social malfunctioning [emphasis in the original] (Biesta and Lawy, 2006: 71).

Biesta and Lawy acknowledge that what ended up as citizenship in the National Curriculum 'was considerably different to the recommendations of [Crick]' (Biesta and Lawy, 2006: 71), emphasising particularly the loss of much that Education for citizenship included in the category of political literacy. In terms similar to those advocated in Education for citzenship, Biesta and Lawy regard active citizenship as exemplified through 'a culture of participation ... the learning of democratic citizenship is situated within the lives of young people' [emphasis in the original] (Biesta and Lawy, 2006: 72, 73). Political literacy is seen more as part of a practice than as an academic subject of study. The 
knowledge, skills and values that comprise political literacy are used in order to 'learn democracy' (according to Biesta and Lawy). This involves questioning what 'active' or 'participatory' citizenship means rather than taking these terms as given. According to the authors,

young people learn at least as much about democracy and citizenship from their participation in the range of different practices that make up their lives, as they learn from that which is officially prescribed and formally taught (Biesta and Lawy, 2006: 73).

\section{Citizenship and politics as conflict: Chantal Mouffe}

For Mouffe, politics is a site of conflict rather than consensus. In Agonistics, she states:

To think politically requires recognizing the ontological dimension of radical negativity. It is because of the existence of a form of negativity that cannot be overcome dialetically that full objectivity can never be reached and that antagonism is an ever present possibility (Mouffe, 2013: loc. 42).

Mouffe's point is that consensus is not a realistic or appropriate state-of-affairs for a body politic to strive towards. This is not to say that Mouffe's depiction of agonism (or conflict) is violent or destructive - it is an acknowledgement that any gains (in terms of rights, an increase in the franchise or access to positions of power, for example) that have been made by dispossessed or disadvantaged groups in a society have been through struggle with the dominant forces. Mouffe sees this constant push-and-pull between different groups in society as an inevitable and recurring situation as power is obtained, lost and regained. This is what Mouffe refers to as 'the permanence of antagonistic forces' (Mouffe, 2005: 53). What prevents these forces from creating paralysis is, in Mouffe's words, a creation of a 'we' in contradistiction to a 'them' or Other:

Political life concerns collective, public action; it aims at the construction of a 'we' in a context of diversity and conflict. But to construct a 'we' it must be distinguised from a 'them', and that means establishing a frontier, defining an 'enemy'. Therefore, while politics aims at constructing a political community and creating a unity, a full inclusive political community and a final unity can never be realized since there will permanently be a 'constitutive outside', an exterior to the community that makes its existance possible [emphasis added] (Mouffe, 2005: 69).

The implications of Mouffe's observations on political literacy (and citizenship education generally) are potentially immense. How is the issue of conflict to be articulated and facilitated within contemporary classrooms? This is a particularly 'live' issue in England currently, where the government is insisting on the promotion of 'fundamental British values' in schools and colleges. If, as Mouffe argues, 'a full inclusive political community ... can never be realized', how 
are students to use their political literacy, especially if they perceive themselves to be part of the 'constitutive outside'?

Summary of citizenship education and political literacy in relation to philosophy of education

How citizenship education (and the knowledge, skills and values incorporated within the concept of political literacy) is informed and problematised by issues within the wider fields of political philosophy and philosophy of education is a complicated concern. This is because the concept of citizenship has itself become a contentious political and philosophical issue. Over the past several decades, the connection between the nation state, political power and citizenship has been questioned from a variety of perspectives including the rise of continental and global political institutions, the demand for regional and lingusitic freedoms and liberties, and the increasing association between identity, lifestyle and political values.

The debate over consensus and diversity has affected our notions over what constitutes political literacy in schools and colleges. Liberal states have attempted to remain 'neutral' amongst reasonable conceptions of the good, acknowledging that contemporary democracies are inherently multicultural. Much that goes by the way of citizenship education and political literacy has endeavoured to explore the 'overlapping consensus' (to borrow Rawls's term) in which students and teachers from different ethical perspectives or worldviews can engage in critical debate and discussion in an atmosphere of mutual respect. But Mouffe has argued that ongoing conflict and struggle is endemic in any political state and this idea, if sound, has considerable ramifications for citizenship education. Political literacy, on these terms, is (potentially) a set of tools or strategies to challenge the very system in which education is taking place. This becomes especially fraught in a political atmosphere where 'radicalisation' and 'fundamental British values' are watchwords for education ministers and government inspectors.

Is citizenship a discipline to be studied or a practice to engage in? Biesta and Lawy have argued that the neo-liberal focus on individualism has been reflected within citizenship education. Political literacy (as envisaged by Crick and his committee) has been sidelined in an attempt to create a programme of study to emphasise individual responsibility and social cohesion over and above the need for students to critique society from within the range of contexts in which they find themselves. What it means to be an 'active' citizen is not a given but requires analysis by young people as part of their investigation of political literacy.

The role of the Levellers will be placed in their historical context in the next section. As stated above, much of the recent focus in political philosophy regarding citizenship has been within the so-called 'liberal v. communitarian' debate. Whilst it is important not to be anachronistic and either place the Levellers into contexts they could never have envisaged or project contemporary 
thought backwards into seventeenth-century England, the Levellers do have pertinence in relation to contemporary citizenship. They were agitating and writing at a time when the relationship of the individual to society was beginning to gain political traction. In this sense, we can say that the Levellers were early advocates of inalienable individual rights and provide strong historical links between Magna Carta and the formulation of the American Bill of Rights (for example). However, the Levellers' thought was also rooted in the deep religious debates and divisions that were specific to that moment in time in English history. They were not 'universalists' in the modern liberal interpretation and this tension between arguing for individual rights and writing within a very specific tradition and context makes the Levellers (in our view) very interesting when encouraging students in the twenty-first century to think about the relationship between rights, identity, culture and the role of conflict within the field of citizenship.

\section{The Levellers in their historical context and recent historiography on their influence}

On 28 October 1647, soldiers and officers of the New Model Army, then the sword behind the victorious Parliamentary government in the first English Civil War, with civilian representation, met in St Mary's Church, Putney in South-West London, to discuss the future of England. Their debates included the vexed issue of whether they should negotiate with the defeated King Charles I, but also whether there should even be a King or a House of Lords. Unusually they also considered the widening of the franchise to include all men. Ultimately the army leaders, including Oliver Cromwell turned their faces against such 'anarchy' and the Levellers who agitated for radical change would be defeated by military force, but the 'Leveller moment' has a lasting legacy in political discourse and in historical understanding, providing the spectre of popular radicalisation for some, that informed attempts to limit or buy off popular influence in the nation's politics and for others it marked a missed opportunity, where England could have seen a popular revolution and a radical democratic shift. It also provides evidence that 'the people' were also part of the structure of English politics' and the possibility that, just below the surface, the 'Many-Headed Monster' of popular sentiment or a Hobbsian Leviathan, waiting to rise from the waves.

For these reasons the Levellers were largely dismissed or ignored by historians of the Civil War until the early twentieth century. A threat to the ruling classes was an unwelcome aberration in the Whig view of inexorable progress towards a parliamentary constitutional monarchy that was 'the best of all possible worlds'. From the publication in 1916 of Theodore Calvin Pease pamphlet on Leveller political theory, there was a rediscovery of the movement (Pease, 1916). The difficulty was how to place the 'out of place' Levellers in context. As Rachel Foxley (2013: 1-2) points out, historians of this period variously saw them, anachronistically, as 'democrats' and 'liberals'. This phase came to an end in the 
1960s and the leading figures studying the movement would be, like one of the greatest historians of the era, Christopher Hill, Marxist in sympathy. Hill's The World Turned Upside Down (1972), was a milestone in the recovery of the 'people's history' that would begin to dominate the next decades and his work was important in separating the 'bourgeois revolution' of the landholders in Parliament, from the failed 'plebeian revolution' that followed. However, Hill afforded much more weight to the Diggers, the 'true Levellers', who were more clearly proletarian, advocated more direct action by disputing land ownership and who fitted much better with a Marxist ethos.

The Levellers were inevitably caught up in the wave of revisionism that confronted the civil war from the early 1970s and into the 1990s. The clear lines of 'Revolution' began to break down as detailed studies emerged of both what happened in at the centre, as in the work of Conrad Russell (1973), and in the localities, of which John Morrill (1974) is among the most significant. Works that managed to combine these increasingly complicated worlds like, those of Anthony Fletcher (1975), began to present a picture of shifting loyalties and pragmatism. In these circumstances the major impact on the study of the Levellers was to make them seem much less relevant. If mid-seventeenth century England was not revolutionary, then they could not be revolutionaries, or at least relevant ones. The significance of the Levellers was downplayed by historians such as Mark Kishlansky (1975) and the unity and even existence of a 'Leveller movement' has also been disputed by Jonathan Scott (2000: 270-1) and Diane Purkiss (2006: 476).

More recently there has been a revival of interest in the Levellers and their significance. This has been partly driven by a post-revisionist phase in Civil War studies, which accepts the main findings of revisionism, but which seeks to find new understandings of the period in context, and partly by a series of anniversaries and perhaps also by an increasing interest in the relationship between Leveller ideas and the rise of modern populism, particularly on the left. These include studies of the Putney debates that began with collections of essays edited by Michael Mendel (2001) and G. Robertson, (2007), and on The Agreements of the People that emerged from the debates, edited by Baker and Vernon (2012). Then, the first monographs on the Levellers since 1961 have begun to emerge. These include Foxley's The Levellers: Radical Political Thought in the English Revolution (2012) and in a more popular and polemical vein, John Rees's The Leveller Revolution (2016). While the former stresses the wider context of the Levellers and the processes behind their development, Rees adopts a narrative mode that leans back toward Marxist interpretations of the events of the 1640 s.

\section{Contextualising the Levellers}

The name 'Leveller' came from the tradition of popular rural protest that existed in England, particularly focused on resistance to changes in agricultural practice and ownership. It was used in the Midland Riots of 1607, because the rioters levelled the hedges that divided and enclosed previously common land (Scott 
and Cavanaugh, 2008: 385) and was probably applied to the political movement that arose towards the end of the first civil war around 1644 by its opponents, particularly the pamphleteer Marchamont Needham. In its early stages members of the movement, like John Lilburne, preferred to think of themselves as 'agitators'. The name was an insult and recalled not only the earlier rioters, but suggested that they might level society and end property ownership. It was not widely adopted by the movement until after four leaders, including Lilburne, produced a manifesto from prison in 1649. They called themselves Levellers, probably because that was the name by which they were most widely known (Worden, 2001: 280-82).

Just as it is difficult to pin down the Levellers as a term, their aims and ideas are complex and hard to define. Their agenda developed rapidly in the confused political situation in the aftermath of the first civil war. In the same way as some historians have come to deny the idea of a Leveller Movement, it is equally difficult to identify a Leveller Programme. The leading figures draw on sources of traditional sources of Parliamentary and oppositional rhetoric, including ideas of the English Common Law, the Norman Yoke and Magna Carter, but without any clear consensus (Edwards, 2007: 44-45). They moved into areas of anticorruption, religious toleration, the widening of the franchise, although in no way did represent a fully democratic movement in the modern sense, excluding servants and women from the planned representation and the idea of natural rights, all in a religious context in which these were seen as granted by God. What is more, although they have received much attention as democracy has become a reality in much of the world and an ambition elsewhere, it is not clear that it was central to the Leveller agenda. Instead recurring demands focused on limiting the negative and blocking power of the House of Lords and the King (Foxley, 2013: 175).

The origins of the movement were probably in the agitation for greater representation in London civic government during the early years of the war and from here it gained a foothold among the junior officers and ordinary ranks of the New Model Army (Wood, 2001: 100). In the early stages the writings and pamphleteering of Lilburne, himself once a clothmaker's apprentice in London, was particularly significant. Other figures that became associated with the movement included the pamphleteer Richard Overton, medical practitioner William Walwyn, lawyer John Wildman and the MP and Colonel Thomas Rainsborough. The election of agitators from each regiment in the army and their recognition by the Army's commanders and the publication of their proposals for the dissolution of parliament and changes to the nature of future parliaments led in The Case of the Army Truly Stated in September 1647, led the Grandees commanding the army to demand that the agitators give and account of their claims before a General Council of the Army, which led to the 'Putney Debates' at St. Mary's church. The presentation of the manifesto of the Agreement of the People in October 1647 threatened the settlement that had been endorsed by the General Council, known as the Heads of the Proposals, which optimistically relied on striking an agreement with the imprisoned king, Charles I. After some soldiers refused to accept the Heads of the Proposals, there were arrests and one ringleader, Private Richard Arnold was executed, but although dissent was 
suppressed in the army, it continued elsewhere. The petition To The Right Honourable The Commons of England, presented to Parliament on 11 September 1648, managed to gain widespread support from the inhabitants of London. The funeral of Rainsborough, after his killing by Royalists in October 1648, was the occasion for a large demonstration in London, Thousands of mourners wore ribbons of sea green, Rainsborough's colours, and bunches of rosemary in their hats, which now became associated with the Leveller cause.

This was arguably the high-water mark of Leveller popular support. After the execution of the king in early 1649 , the Grandees that commanded the army banned petitions from soldiers to Parliament. Objectors were cashiered from the army and when soldiers mutinied, as at Bishopsgate in February, soldiers were arrested, court martialed and some executed. Lilburne, Walwyn, Thomas Prince, and Richard Overton were imprisoned. Cromwell used force to suppress 400 mutineers at Banbury, remaining leading Agitators were arrested or shot and without leadership the movement disintegrated within the army as many of the regiments were shipped to Ireland. It reared its head occasionally in the 1650s, sometimes as part of a conspiracy and more forcibly when the Republic collapsed in 1659, but the realistic opportunity for implementing a political programme had gone. As Tim Harris put it 'this was very much the end' (Harris, 2001: 219)

What, if anything did the Levellers achieve? This topic has been hotly debated by historians. The short answer is that they managed very little. Even within the limited terms that on which they had consensus and particularly the issues of the franchise, they failed to have a major impact on the ultimate settlement that Cromwell would pursue (but fail to achieve) until his death in 1658 and which would, in any case be overturned at the Restoration of the Monarchy in 1660. For many Marxists, like David Petegorsky and Christopher Hill, they represented the interests of the 'petit bourgeoisie' and their legalism and religious roots doomed them to failure (Worden, 2001: 278). More recent interpretations that have tended to emphasise the confused and diffuse nature of both Leveller thinking and organisation, suggest that they were unable to capitalise on the circumstances of the aftermath of the civil war because those circumstances mitigated against the possibility of political power. Nevertheless, as an event in the course of political and social history the Levellers have had a recurring fascination, prefiguring in the view of many: democracy, individualism, and social and political revolution (Worden, 2001: 279-80).

\section{Influence}

As a subject of interest the Levellers have had a much more vivid life then they did as a political force. Leveller ideas do not seem toa major force in Restoration England. Blair Worden observes that, while they might have made propaganda 
fodder for the Royalists, their targets were more often surviving republicanism and sectarians of 'The Good Old Cause' (Worden, 2001: 265-6). More positively Tim Harris (2001: 225) points to the use of Leveller motifs, such as green tokens, in events such as the Bawdy House Riots of 1668 and Weavers Riots of 1675. Their ideas resurfaced occasionally in tracts like that attributed to John Wildman and published in the crisis years of 1688-9. There are resonances of their ideas in the radical reformers of William III's reign, the Commonwealthmen, whose leading figures John Trenchard and John Toland opposed parliamentary supremacy by arguing that the people only leant their sovereignty to their representatives, but whose solutions were in a narrowing of the franchise to the incorruptible rich, in a reverse of Leveller ambitions. The Whigs, while quite clearly not Levellers, also used Leveller rhetoric and methods of popular persuasion that harked back to the 1640s (Harris, 2001: 235-6).

The Levellers had little or no notable impact on the politics of the eighteenth century and 'levelling' only seems to have entered political discourse as an accusation of general desire to impoverish the ruling classes. When popular and parliamentary radicalism emerged as a force in the late eighteenth century it made almost no reference to the Levellers that had come before (Worden, 2001: 269-70). Catherine Macaulay, who argued that the Levellers had been neglected and maligned, was a lone historical voice in the period (Macaulay, 1768: 355). They garnered occasional mentions in the nineteenth century from figures such as Coleridge and the republican historian J. T. Rutt, but the term Leveller remained an insult and was often cast at political reformers such as the Chartists, who, along with a few republicans, did take an interest in the movement, but it is not clear that they felt that they were part of a continuous political movement or that the Levellers were more than distant common ancestors (Worden, 2001: 272).

Traditional histories of the period put an emphasis on constitutional and religious argument, mostly among the social elite in parliament and in the postwar period, on the figure of Cromwell, seen positively on all sides, as in opposition to the Levellers. The Whig view that dominated had little time for untaken roads on the high road to constitutional parliamentary democracy. Largely neglected until the twentieth century, interest revived as socialism began to become a serious political movement and one that naturally began to look for its roots in the past (Worden, 2001: 259-62). As such, the Levellers began to present an opportunity to produce and alternative historical narrative to that of the Whigs, one that could put an emphasis on ideas of liberty and equality.

As such the Levellers also remain an opportunity to provide alternative understandings of history to those common in contemporary political rhetoric and education. They were not temporally displaced democrats or socialists, and that danger needs to be guarded against. However, they do represent an opportunity to produce an alternative view of history and of political participation, which is more than the simplistic and teleological view of history as a process of inevitability. In this sense the failure of the Leveller moment is more significant than for its limited achievements, as this serves as a reminder that what seems inevitable in retrospect, might have been very different paths taken. Furthermore, they evidence the existence of a history of the many, rather 
than the few, and that there were alternative views of what constituted the state and the citizen at least as far back as the mid-seventeenth century.

\section{How could the study of the Levellers inform the concept of political literacy and active citizenship within Citizenship in the English National Curriculum?}

We have already shown how Crick, in his report of 1998, defined political literacy (in terms of Citizenship within the National Curriculum) as:

Pupils learning about ... how to make themselves effective in public life through knowledge, skills and values - what can be called 'political literacy', seeking for a term that is wider than political knowledge alone (QCA, 1998).

We have also demonstrated (in the previous section) that the achievement and influence of the Levellers (in their contemporary context and afterwards) is a complicated one. So can we draw links between Crick's concept of political literacy and the Levellers as historical exemplars?

There is relatively little on the Levellers in terms of the Citizenship programme of study (they tend to be covered in History curricula and resources, eg. BBC History (BBC, 2011) and Edexcel/Pearson (2015) AS and A Level Topic Booklet (Route C: Revolutions in early modern and modern Europe)). However, there are genuine opportunities to explore the Levellers as part of a wider study of Citizenship. AQA, for example, in their recent 'GCSE Citizenship Studies' course specification speaks of

The rights, responsibilities and role of the media and a free press in informing and influencing public opinion, providing a forum for the communication and exchange of ideas and opinions, and in holding those in power to account (AQA, 2016: 9).

It is not making unrealistic or inappropriate connections to Crick or the current Citizenship curriculum to argue that the Levellers' use of pamphleteering and other forms of written and oral agitation (over such controversies as expansion of the franchise) relates well to contemporary issues over citizenship, news/fake news and the use of social media. The mid-seventeenth century was the age of the political pamphleteer, as rising rates of literacy, particularly among men, combined with cheap popular print and the breakdown of the system of censorship due to the civil wars. At the end of the first war in England the Royalist propaganda and early parliamentary rhetoric of loyalty to the crown while fighting its holder, gave way to a radicalisation and free-for all of publication (Como, 2012, p. 820). In this process Glenn Burgess has characterised the Levellers as 'masterful political pamphleteers' (Burgess, 1993, p. 45). They made use of a tradition of Protestant political polemic that would have been familiar to their readership to argue for their views. The gradual 
emergence of mass literacy brought the use of the written word as part of political demonstration to the very fore. The Levellers were adept at using the latest technologies (printing and distribution of political tracts on cheap paper) to gain a wide readership. The notions of a 'free press' grew out of such an environment and have implications for us in an age of digital and online communication. But what are these implications? The benefits and drawbacks of pamphlettering and the 'free press' in the seventeenth century and the digital social media of today are quite closely related. What we find in both periods is the relative freedom of people to express their political views in writing without going through gatekeepers and censors in order to express such views. These media were/are also sensitively attuned to particular audiences and put processes in place in order to get material quickly and efficiently to these readers. The drawbacks are, to some extent, the flipside of these freedoms. Because there was/is no gatekeeper or editorial filter, pamphlets and tweets are both vulnerable to abuse and misuse - the peddling of 'fake news' (to use a recent phrase) to generate action or change opinion. In terms of Citizenship education, it is important for students to recognise the freedoms and dangers associated with political discussion from unmediated sources and to be mindful of how they use technology to voice their own opinions and viewpoints. Although the technologies of the small printing press and the mobile phone are very different, the processes and effects they had or are having on political discourse do contain certain similarities. We think encouraging students to make and draw upon such comparisons are likely to be beneficial for their own political literacy.

The concern is that the current programme of study for Citizenship in the National Curriculum (as outlined at the beginning of this paper) tends towards instrumental knowledge (parliamenary processes and legal jurisdictions) rather than encouraging students to participate as emerging citizens within their own communities. There is a danger, within such programmes of study, of assumptions (pace Biesta and Lawy) about what 'good' citizenship is rather than encouraging students to question what constitutes a 'good' citizen. The Putney Debates are instructive here, especially the discussion between Ireton and Rainsborough on whether there should be a minimum proprerty requirement before a (male) adult could vote. This debate asked fundamental questions on whether someone had to have a vested interest or concern (usually in the form of landed property) to be able to affect national policy and legislation. Can someone who does not 'own' (or have a significant investment in) a portion of the society in which they live part still play a role as citizen? Current discussion on taxation, welfare rights and property ownership are very much 'live' issues regarding contemporary citizenship where the Levellers have arguments that are pertinent to the Citizenship classroom. We having been living through a period in recent political history when the United Kingdom was purportedly a 'property-owning democracy' and, it could be argued, that rhetoric is becoming increasingly hard to substantiate. The Levellers asked the question over whether property ownership was a necessary requirement to gain full political rights. Whilst that particular debate no longer has currency with regards to voting rights, the discussion over appropriate housing, benefits and political agency has a very real significance in today's social climate. Is adequate housing an 
entitlement (as is often enshrined in social, economic and cultural rights) and, if so, an entitlement for whom? To what extent does access to housing and other welfare benefits enable citizens to play an active part in their communities? Whilst the focus has changed between the time of the Putney Debates and the today's Citizenship classroom, discussion of what is essential or necessary to enable people to articulate their full political rights is very much to the fore with young people in England (and elsewhere) today.

The role conflict plays in politics and citizenship is also critical. We have already seen, in discussion of Chantal Mouffe, that conflict is an inevitable and necessary aspect of any democratic society. We are now living in an educational landscape populated with Fundamental British Values (DfE, 2014) and the PREVENT agenda (DfE, 2015) to counteract radicalisation and terrorism. The leaders of the Levellers (Walwyn, Lilburne, Prince and Overton) were themselves incarcerated in the febrile political atmosphere that occurred during and immediately after the trial and execution of Charles I. The Levellers were often depicted in pamphlets and broadsides as agitators dangerous to public safety and the stability of the realm. What it meant to be English was a deep and volatile question in mid-seventeenth century England. It is not difficult to draw parallels between this political context and our own. The Levellers can be seen on a timeline that also involves the Chartism and the early trade unionists, the Suffragette movement, the struggle for post-colonial independence in Africa and Asia, and the Civil Rights movement in the United States of the 1950s and 1960s and in Northern Ireland in the late 1960s. There is also potential currency today in making connections with 'Occupy' and other groups concerned with neoliberalism, transnational corporations and the increasing disparities in wealth within contemporary industrial societies and between the Global North and South. All of these movements and organisations have had to challenge and even break the law to achieve what are now considered fundamental and integral democratic rights. In this sense, the Levellers are asking questions that go to the heart of the liberal/communitarian debate on individual rights discussed earlier in this paper. Mention could also have been made of Gerard Winstanley and the Diggers - for reasons of space, we have not been able to address the important contribution the Diggers made to political debate during and after the Civil War but their example is pertinent to the contemporary Citizenship classroom and curriculum, especially with regards to equality and ownership.

What is the relationship between the 'good' citizen, the rule of law and the inevitability of challenge and conflict in any multicultural, democratic society? In terms of Citizenship education, this will partly depend on whether we see citizenship as a set of skills to acquire and develop or whether it is something closer to our own personal identity (and the relationship this has to the communities in which we play an active part). Citizenship can be conceived as a set of skills and practices students learn (although Biesta and Lawy have been critical of the neoliberal, individualistic slant this tends to put on Citizenship education). Without wishing to over-romanticise the Levellers, whilst they were effective in many of the skills and practices we might associate with citizenship, to them it was more than an accumulation of skills and practices. Alongside their 
associates and enemies, they helped to foster a political culture where literacy, debate and conflict were inextricably bound together. These groups helped to promote what we would now term 'active citizenship' - a sense that political discussion and engagement helps to frame and expand who we are (for both good and ill). The Agreement of the People is more than a roadmap for skills in citizenship - it is questioning the political structures that dominated midseventeenth century England and demanding a wider conception of citizenship. Children and young people, if they are to articulate the notions of 'active citizenship' and 'political literacy' in the classroom and beyond, need to be asking themselves similar questions to the Levellers.

\section{Conclusion}

It is hoped we have been able to make a case for using the historical ideas and practices of the Levellers to inform the study of Citizenship in the contemporary classroom. It is a truism that there can never be a direct translation from one historical era to another. However, we think there are pertinent and creative connections between the situation in mid-seventeenth century England and its early twenty-first century equivalent to merit the study of political literacy (and the active citizenship it hopefully engenders) during these two eras. Questions of individual rights, the body politic and identity, and how the state manages conflict are integral to the political situation in both historical periods. A comparison would be of genuine benefit to today's students.

We have seen, through the work of Biesta and Lawy, that it is not enough just to assume that 'good citizenship' is a given, a concept that has near universal agreement on its definition or the values and behaviours nested within it. Disagreement on this (from political, religious and philosophical perspectives) is probably inevitable and conflict of the sort Chantal Mouffe has identified is currently with a political reality in England. It is important for students to recognise that conflict is nothing new - it is endemic to discussion and action in any state and at any time. The Levellers lived, wrote and campaigned at a time of heightened tensions in the English body politic. Citizenship, as a foundation subject within the English school curriculum, needs to engage with their example if political literacy is to be taken seriously by students and educationalists alike.

\footnotetext{
* The authors would like to thank the comments from an anonymous reviewer in the development of this paper
} 


\section{References}

AQA (2016), GCSE Citizenship Studies [course specification 8100, Version 1.0, 17 March 2016], [online]. Available at:

http://filestore.aqa.org.uk/resources/citizenship/specifications/AQA-8100-SP2016.PDF (accessed 19 July 2017).

Baker, P., and Vernon, E., (eds.) (2012), The Agreements of the People, the Levellers, and the Constitutional Crisis of the English Revolution, Dordrecht: Springer.

BBC (2011), The Levellers and the Tradition of Dissent [online]. Available at: http://www.bbc.co.uk/history/british/civil war revolution/benn levellers 01.s

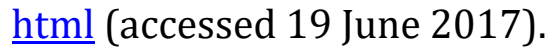

Biesta, G. and Lawy, R., (2006), From teaching democracy to learning democracy: overcoming individualism in research, policy and practice, Cambridge Journal of Education, 36 (1): 63-79.

Burgess, G., (1993), Protestant polemic: the Leveller pamphlets, Parergo 11 (2): 45-67.

Como, D. (2012). Print, Censorship, and Ideological Escalation in the English Civil War, The Journal of British Studies, 51(4): 820-857.

Department for Education (DfE) (2013), National curriculum in England: citizenship programmes of study for key stages 3 and 4 [online]. Available at: www.gov.uk/government/publications/national-curriculum-in-englandcitizenship-programmes-of-study/national-curriculum-in-england-citizenshipprogrammes-of-study-for-key-stages-3-and-4 (accessed 23 March 2016).

DfE (2014), Guidance on promoting Btitish values in schools [online]. Available at: https://www.gov.uk/government/news/guidance-on-promoting-britishvalues-in-schools-published (accessed 19 June 2017).

DfE (2015), Protecting children from radicalisation: the prevent duty [online]. Available at: https://www.gov.uk/government/publications/protectingchildren-from-radicalisation-the-prevent-duty (accessed 19 June 2017).

Edward, J., (2007), The Radical Attitude and Modern Political Theory, Dordrecht: Springer.

Edexcel/Pearson, (2015) AS and A Level in History Topic Booklet (Route C: Revolutions in early modern and modern Europe, London: Pearson. 
Enslin, P., Pendlebury, S. and Tjiattas, M., (2001), Deliberative Democracy and the Challenges of Citizenship Education, Journal of Philosophy of Education, 35 (1): 115-130.

Fletcher, A., (1981) The Outbreak of the English Civil War, London: Edward Arnold.

Foxley. R., (2013), The Levellers: Radical Political Thought in the English Revolution, Manchester: Manchester University Press.

Kishlansky, M., (1979), The Rise of the New Model Army, Cambidge: Cambridge University Press.

Macaulay, C., (1768), The History of England from the Accession of James I to the Revolution, Volume IV.

Matravers, D. and Pike, J.,(eds.) (2003), Debates in Contemporary Political Philosophy: An Anthology, London: Routledge/Open University.

Mendel, M., ed. (2001), The Putney Debates of 1647, Cambridge: Cambridge University Press.

Morrill, J., (1976) Revolt of the Provinces: Conservatives and Radicals in the English Civil War, 1630-1650, London: Allen \& Unwin.

Mouffe, C., (2005 [1993]), The Return of the Political, London: Verso.

Mouffe, C., (2013), Agonistics: Thinking the World Politically [electronic book], London: Verso.

Papastephanou, M., (2005), Rawls' Theory of Justice and Citizenship Education, Journal of Philosophy of Education, 39 (3): 499-518.

Pease, Theodore Calvin, (1916), The Leveller Movement: A Study in the History and Political Theory of the English Great Civil War, American Historical Association.

Purkiss, D., (2006), The English Civil War, A People's History, London: Palgrave.

Qualifications and Curriculum Authority (QCA) (1998), Education for citizenship and the teaching of democracy in schools, London: QCA.

Robertson, G., ed., (2007), The Levellers, The Putney Debates, London: Verso.

Russell, C., ed., (1973), The Origins of the English Civil War, London: Macmillan.

Scott, J., (2000), England's Troubles, Seventeenth-Century English Political Instability in European Context, Cambridge: Cambridge University Press. 
Scott, P., and Cavanaugh, W. T., (eds.) (2008), The Blackwell Companion to Political Theology, London: John Wiley \& Sons.

Trexler, R. C., (1985), Persons in Groups: Social Behavior as Identity Formation in Medieval and Renaissance Europe, Medieval \& Renaissance Texts \& Studies, 1985.

Wood, A., (2001), Riot, Rebellion and Popular Politics in Early Modern England, London: Palgrave Macmillan. 